\title{
Prevalence and analysis of respiratory and anthropometric parameters in patients with obstructive sleep apnea
}

\author{
Prevalência e análise de parâmetros respiratórios e antropométricos de pacientes com apneia \\ obstrutiva do sono \\ Prevalencia y análisis de parámetros respiratorios y antropométricos en pacientes con apnea \\ obstructiva del sueño
}

Received: 03/01/2021 | Reviewed: 03/08/2021 | Accept: 03/09/2021 | Published: 03/17/2021

Danilo Sobral da Silva Fernandes

ORCID: https://orcid.org/0000-0002-8396-2613

Faculdade São Francisco de Juazeiro, Brasil E-mail: danilosobra@gmail.com

Manoel Pereira Guimarães

ORCID: https://orcid.org/0000-0001-7780-8946 Universidade Federal do Vale do São Francisco, Brasil

E-mail: manoelpeguimaraes@gmail.com

Einstein Zeus Alves de Brito

ORCID: https://orcid.org/0000-0002-3340-8702

Faculdade São Francisco de Juazeiro, Brasil

E-mail: einsteinzeus@outlook.com

João Diego Cabral Lima

ORCID: https://orcid.org/0000-0003-2825-1971 Universidade Federal do Vale do São Francisco, Brasil

E-mail: joaodiegocabral@gmail.com

Mateus de Sousa Rodrigues

ORCID: https://orcid.org/0000-0003-4664-2351 Universidade Federal do Vale do São Francisco, Brasil

E-mail: mateuserem@gmail.com

Victor Ribeiro Neves

ORCID: https://orcid.org/0000-0002-3294-2700 Universidade de Pernambuco, Brasil

E-mail: victor.neves@upe.br

Bruno Bavaresco Gambassi

ORCID: https://orcid.org/0000-0003-3852-0602 Universidade Ceuma, Brasil

E-mail: professorbrunobavaresco@gmail.com

Paulo Adriano Schwingel

ORCID: https://orcid.org/0000-0002-2935-3403

Universidade de Pernambuco, Brasil

E-mail: paulo.schwingel@upe.br

Fabrício Olinda de Souza Mesquita

ORCID: https://orcid.org/0000-0003-3761-368X

Universidade Federal do Vale do São Francisco, Brasil

E-mail: fabricio.souza@ebserh.gov.br

\begin{abstract}
Introduction: Obstructive sleep apnea is a condition characterized by frequent respiratory pauses lasting $\geq 10$ seconds, accompanied by desaturation/reoxygenation cycles and repetitive arousals triggered by complete (apnea) or partial (hypopnea) cessation of airflow during sleep. Objective: To determine the prevalence and to assess the respiratory and anthropometric parameters of patients with obstructive sleep apnea in Vale do São Francisco area. Methods: This is a descriptive, cross-sectional study using secondary data collected from 466 patients between June 2015 and June 2017. Patients who underwent home polysomnography were included while those who did not perform the lung function test and/or failed to present a medical report were excluded. Results: Obstructive sleep apnea was observed in $79.2 \%$ $(n=126)$ of the patients enrolled. Cases with greater severity were observed in males and were more prevalent among those aged 60 years or above. Forced expiratory volume in 1 second $(P=0.006)$ and forced vital capacity $(P=0.001)$ decreased with increased obstructive sleep apnea severity. Significant correlations were observed between the severity of obstructive sleep apnea and age, body mass index and Apnea-Hypopnea Index, while pulmonary function variables presented a low negative correlation with obstructive sleep apnea severity. Conclusion: Greater severity of obstructive
\end{abstract}


sleep apnea was more prevalent in males and the involvement of the pulmonary function was more pronounced in the groups with severe obstructive sleep apnea. Reductions in lung function were also found in this population, with negative linear correlations between ventilatory parameters and obstructive sleep apnea severity.

Keywords: Obstructive sleep apnea syndrome; Sleep disorders; Epidemiology; Diagnosis; Complications.

\section{Resumo}

Introdução: A apneia obstrutiva do sono é uma condição caracterizada por pausas respiratórias frequentes com duração $\geq 10$ segundos, acompanhadas por ciclos de dessaturação/reoxigenação e despertares repetitivos desencadeados pela cessação completa (apneia) ou parcial (hipopneia) do fluxo de ar durante o sono. Objetivo: Determinar a prevalência e avaliar os parâmetros respiratórios e antropométricos de pacientes com apneia obstrutiva do sono na região do Vale do São Francisco. Métodos: Trata-se de estudo transversal descritivo feito a partir de dados secundários de 466 pacientes avaliados entre junho de 2015 e junho de 2017. Foram incluídos os pacientes que realizaram a polissonografia domiciliar. Dentre esses, foram excluídos os pacientes que não realizaram o teste de função pulmonar e/ou exames que não apresentaram laudo médico. Resultados: Presença de apneia obstrutiva do sono foi observada em 79,2\% $(n=126)$ dos pacientes incluídos. Casos com maior gravidade foram observados no sexo masculino, sendo mais prevalentes após 60 anos de idade. $\mathrm{O}$ volume expiratório forçado no primeiro segundo $(\mathrm{P}=$ $0,006)$ e a capacidade vital forçada $(\mathrm{P}=0,001)$ diminuíram com o aumento da gravidade da apneia obstrutiva do sono. Correlações significativas foram verificadas entre a gravidade da apneia obstrutiva do sono com idade, índice de massa corpórea e Índice de Apneia-Hipopneia, enquanto as variáveis de função pulmonar avaliadas neste estudo apresentaram baixa correlação negativa com gravidade da apneia obstrutiva do sono. Conclusões: Foi constatada maior gravidade da apneia obstrutiva do sono nos homens e maior comprometimento na função pulmonar nos grupos com apneia obstrutiva do sono grave. Reduções na função pulmonar também foram identificadas nessa população com correlações lineares negativas entre os parâmetros ventilatórios e a gravidade da apneia obstrutiva do sono.

Palavras-chave: Síndrome da apneia obstrutiva do sono; Distúrbios do sono; Epidemiologia; Diagnóstico; Complicações.

\section{Resumen}

Introducción: La apnea obstructiva del sueño es una condición caracterizada por pausas respiratorias frecuentes de $\geq$ 10 segundos, acompañadas de ciclos de desaturación/reoxigenación y despertares repetitivos desencadenados por cese completo (apnea) o parcial (hipopnea) del flujo aéreo durante el sueño. Objetivo: determinar la prevalencia y evaluar los parámetros respiratorios y antropométricos de pacientes con apnea obstructiva del sueño en el área del Valle de São Francisco. Resultados: Se observó apnea obstructiva del sueño en el 79,2\% (n = 126) de los pacientes incluidos. Se observaron casos de mayor gravedad en varones y fueron más prevalentes entre los de 60 años o más. El volumen espiratorio forzado en 1 segundo $(\mathrm{P}=0,006)$ y la capacidad vital forzada $(\mathrm{P}=0,001)$ disminuyeron con el aumento de la gravedad de la apnea obstructiva del sueño. Se observaron correlaciones significativas entre la gravedad de la apnea obstructiva del sueño y la edad, el índice de masa corporal y el índice de apnea-hipopnea, mientras que las variables de función pulmonar presentaron una baja correlación negativa con la gravedad de la apnea obstructiva del sueño. Conclusión: la mayor gravedad de la apnea obstructiva del sueño fue más prevalente en los hombres y la afectación de la función pulmonar fue más pronunciada en los grupos con apnea obstructiva del sueño grave. También se encontraron reducciones en la función pulmonar en esta población, con correlaciones lineales negativas entre los parámetros ventilatorios y la gravedad de la apnea obstructiva del sueño.

Palabras clave: Síndrome de apnea obstructiva del sueño; Trastornos del sueño; Epidemiología; Diagnóstico; Complicaciones.

\section{Introduction}

Obstructive sleep apnea (OSA) is a public health issue currently affecting between 5 and $20 \%$ of the world population (Gautier-Veyret et al., 2018). OSA is a condition characterized by frequent respiratory pauses lasting $\geq 10$ seconds, accompanied by desaturation/reoxygenation cycles and repetitive arousals triggered by complete (apnea) or partial (hypopnea) cessation of airflow during sleep (Canales et al., 2018; Chen et al., 2020). The incidence increases with age, and OSA is more prevalent among males. It is generally associated with obesity (Jehan et al., 2018; Sun et al., 2019) and currently 70\% of Americans with OSA are obese [6]. Anatomical variations can constitute an important risk factor in a lot of cases (Osman et al., 2018).

OSA is also related with the prevalence of cardiovascular diseases, especially those patients whose symptoms are sleep disturbances and excessive sleepiness during the day (Mazzotti et al., 2019). The intermittent hypoxia and the sleep fragmentation also affect the glucose metabolism, thus making OSA a condition being a risk factor do type 2 diabetes (Da Cruz 
Carvalho et al., 2020; Reutrakul \& Mokhlesi, 2017).

Despite the epidemiological relevance of OSA, it remains an underdiagnosed clinical condition that requires early diagnosis to reduce the comorbidities associated with the condition, e.g., cardiorespiratory changes such as interruption of the sleep-wake cycle, increased sympathetic activity, reduced oxygen flow to the brain, arrhythmias and even sudden death (Qian et al., 2016). OSA also increases cardiovascular morbidity (Peppard et al., 2013). Patients diagnosed with OSA are also considered more prominent to automobilistic events (Veasey \& Rosen, 2019).

Anthropometric standards can be related to the severity of OSA, especially neck circumference, waist circumference and the body mass index (Liu et al., 2017). Anthropometric analysis of craniofacial structures makes it possible to identify risk factors (Capalbo et al., 2021; Maresky et al., 2019). Exercise level and dietary composition are also clinical parameters utilized for OSA prognostic previews (L. P. da C. Carvalho et al., 2020; Souto et al., 2020).

In this context, polysomnography (PSG) is considered the gold standard test to identify and assess the severity of OSA (Barbosa et al., 2021; Cunha et al., 2020). Comparing PSG and anthropometric metrics can be a valuable source of information for prognostic of patients with OSA (Genta et al., 2020). For assessing severity, the apnea-hypopnea index (AHI) is commonly used, and it is obtained from PSG by calculating the total apneas and hypopneas events and dividing them by the total sleep time in hours (Sreedharan et al., 2016). PSG is also of immense value on determining the treatment of patients with OSA (Gottlieb \& Punjabi, 2020; Patil et al., 2019).

Regionalization of studies about OSA are of incredible value to determine clinical traits of this pathology in a certain area, with the objective of increasing the number of medical protocols. Given the association between OSA and the increase in cardiovascular morbidity and mortality, along with and the scarcity of studies on clinical variables of patients with OSA, especially on the Northeast, the present study aims to determine the prevalence of OSA and to analyze the respiratory and anthropometric parameters of patients with OSA in Vale do São Francisco area.

\section{Methodology}

\section{Study design}

This is a quantitative, descriptive, cross-sectional study, based on secondary data through medical records collected at Clínica Todo Ser, a referral clinic for patients with OSA in Vale do São Francisco region, located in the city of Petrolina (PE). Data collection took place between June 2015 and June 2017.

\section{Ethical considerations}

The study was approved by the Research Ethics Committee of the Federal University of Vale do São Francisco (CEPUNIVASF) (approval number 2,148,141). The study complies with the revised Helsinki declaration in 2000 and the relevant regulations of the National Health Council (466/2012 and 510/2016). Since this is a retrospective study, the Free and Informed Consent Form (ICF) was waived, according to the CNS 466/12 Resolution.

\section{Sample selection}

Patients who underwent home PSG oriented by Clínica Todo Ser were included. Among these, patients who did not undergo the pulmonary function test and/or failed to present tests together with medical reports for OSA were excluded.

\section{Polysomnography and pulmonary function test}

PSG was performed at home using the ApneaLink ${ }^{\mathrm{TM}}$ device (ResMed Bella Vista, Sydney, NSW, Australia), which records nasal airflow through a pressure transducer, while breathing efforts, pulse rate and peripheral oxygen saturation were 
measured by pulse oximetry. The default device configuration defines apnea as episodes with an $80 \%$ decrease in airflow and hypopnea as events with a 50 to $80 \%$ decrease in airflow, both for a period $\geq 10$ seconds. Desaturation was considered to be a decrease $\geq 4 \%$ of oxygen saturation. The cutoff parameter for diagnosing OSA was AHI $\geq 5$ obstructive events per hour of sleep. The pulmonary function test was performed using the Bodystik ${ }^{\circledR}$ plethysmograph (Geratherm Medical AG, Geschwenda, Germany) to obtain the values of VC, FVC and FEV1 in percentages predicted for age, height, and sex.

\section{Assessment of Covariables}

The body mass index (BMI) in $\mathrm{kg} \cdot \mathrm{m}^{-2}$ and age in years were assessed before the pulmonary function test was performed. The respiratory variables assessed were: lowest oxygen saturation during sleep (SpO2min), obtained from home PSG, the predicted percentage of tidal volume (TD), forced vital capacity (FVC) and forced expiratory volume in 1 second (FEV1), according to the pulmonary function test.

OSA was classified as such: absence of OSA (AHI $<5$ events/hour), mild OSA (AHI between 5 and 15 events/hour), moderate OSA (AHI between 15 and 30 events/hour) and severe OSA (AHI $\geq 30$ events hour) (Sweed et al., 2019).

\section{Statistical analysis}

Continuous variables are presented as mean \pm standard deviation after determining normality using the KolmogorovSmirnov test. Categorical variables are presented in absolute and relative frequencies. Correlations between continuous variables were calculated using Pearson's linear correlation coefficient. Pearson's chi-square test $\left(X^{2}\right)$ was used to compare proportions. Means were compared using one-way analysis of variance (ANOVA) while the Tukey post-test was used to test differences among sample means for significance. A two-tailed test was used, P values were calculated, and the level of significance was set to 5\%. Data were processed and analyzed using Prism (GraphPad Software, Inc., San Diego, CA, USA, Release 6.01, 2012).

\section{Results and Discussion}

Secondary data were collected from 466 patients who underwent PSG in the sample period of which 159 patients remained after using the exclusion criteria. These patients were divided into four groups according to the severity of the disease: patients without OSA (used as a reference for comparison), with mild OSA, with moderate OSA and severe OSA (Figure 1). 
Figure 1 - Flowchart for inclusion in the study.

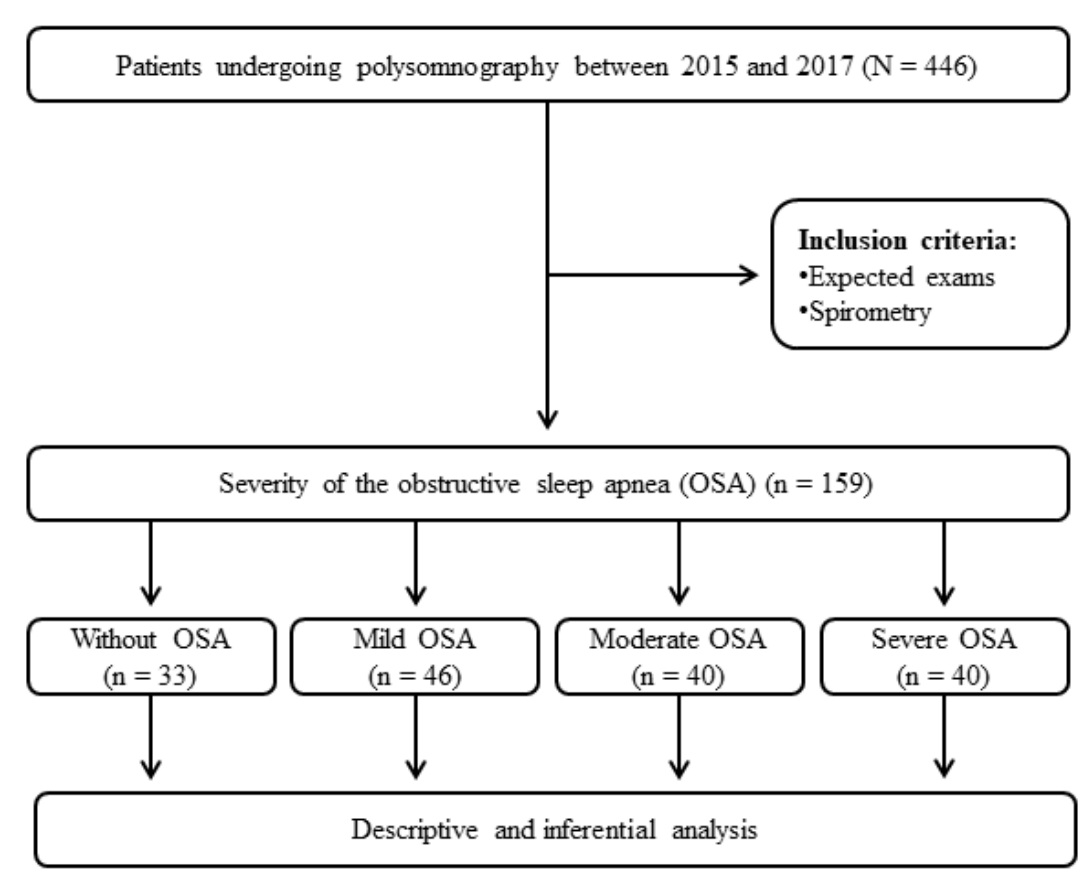

Legend: OSA: obstructive sleep apnea. Source: Authors.

The sample consisted of 159 patients (94 women), with a mean $( \pm$ SD) age of $48.7( \pm 15.5)$ years and BMI $=33.7( \pm$ 8.0) kg.m ${ }^{-2}$. Regarding PSG findings, the mean AHI was 21.4 ( \pm 20.6 ) events/hour (Table 1). 33 and 46 individuals composed the groups without OSA and with mild OSA, respectively, while both moderate and severe OSA groups had 40 patients each.

Table 1 - Clinical characteristics of the patients included in the study $(n=159)$.

\begin{tabular}{ll}
\hline Characteristics & Results \\
\hline Age, Years & $48.7( \pm 15.5)$ \\
Males, n $(\%)$ & $65(41)$ \\
BMI, kg.m ${ }^{-2}$ & $33.7( \pm 8.0)$ \\
AHI, events per hour of sleep & $21.4( \pm 20.6)$ \\
\hline
\end{tabular}

Notes: BMI: body mass index; AHI: Apnea-hypopnea index. Source: Authors.

Moderate and severe OSA were observed in $50.3 \%(\mathrm{n}=80)$ of the patients, while $20.8 \%$ were not diagnosed with the disease. Moderate and severe OSA were more frequent among men $(\mathrm{n}=44 ; 55.0 \%)$. On the other hand, the frequency of patients without OSA was higher in females $(26.6 \%)$, and a statistical association $(\mathrm{P}=0.0029)$ was found between the gender of patients and the classification of OSA severity (Table 2). It was also found that the number of cases of moderate or severe OSA increased with age $(\mathrm{P}=0.0018)$. 
Table 2 - Distribution of patients according to the severity of obstructive sleep apnea and to gender and age group variables.

\begin{tabular}{|c|c|c|c|c|c|c|}
\hline \multirow[b]{2}{*}{ VARIABLES } & \multicolumn{6}{|c|}{ GROUPS } \\
\hline & $\begin{array}{c}\text { Total } \\
\text { sample } \\
(n=159)\end{array}$ & $\begin{array}{c}\text { Without } \\
\text { OSA } \\
(\mathbf{n}=33)\end{array}$ & $\begin{array}{c}\text { Mild } \\
\text { OSA } \\
(n=46)\end{array}$ & $\begin{array}{c}\text { Moderate } \\
\text { OSA } \\
(n=40)\end{array}$ & $\begin{array}{c}\text { Severe } \\
\text { OSA } \\
(n=40)\end{array}$ & $\mathbf{P}^{\mathbf{a}}$ \\
\hline \multicolumn{7}{|l|}{ Gender, n (\%) } \\
\hline Male & $65(40.9)$ & $8(12.3)$ & $13(20.0)$ & $16(24.6)$ & $28(43.1)$ & \multirow{2}{*}{$0.0029 *$} \\
\hline Female & $94(59.1)$ & $25(26.6)$ & $33(35.1)$ & $24(25.5)$ & $12(12.8)$ & \\
\hline \multicolumn{7}{|c|}{ Age range, n (\%) } \\
\hline $19-40$ years & $49(31.4)$ & $17(34.7)$ & $14(28.6)$ & $9(18.4)$ & $9(18.4)$ & \multirow{3}{*}{$0.0018 * *$} \\
\hline $41-60$ years & $72(46.2)$ & $11(15.3)$ & $24(33.3)$ & $18(25.0)$ & $19(26.4)$ & \\
\hline$>60$ years & $35(22.4)$ & $3(8.6)$ & $8(22.9)$ & $10(28.6)$ & $14(40.0)$ & \\
\hline
\end{tabular}

Notes: OSA: Obstructive Sleep Apnea; ${ }^{\text {a }}$ Chi-square test for independent samples; $*$ The statistical difference between genders when the group without OSA was compared to the moderate / severe OSA groups; ** The statistical difference between the age groups 19-40 and> 60 years when the groups without OSA and moderate / severe OSA were compared. Source: Authors.

Anthropometric and respiratory variables were grouped according to the severity of OSA (Table 3). BMI was directly related to severity in patients, and the mean BMI $\left(38.0 \pm 9.4 \mathrm{~kg} \cdot \mathrm{m}^{-2}\right)$ in the severe OSA group was significantly higher when compared to the means of the other groups ( $\mathrm{P}<0.0001)$. The mean percentage of $\mathrm{SpO} 2 \mathrm{~min}$ during sleep showed an inversely proportional association with the severity of OSA: $87.1( \pm 3.9)$ in the group without OSA and at 83.0 ( \pm 5.9$)$ in the mild OSA group. For the moderate OSA and severe OSA groups, the mean percentages were $78.8( \pm 7.1)$ and $70.1( \pm 11.7)$, respectively. The severe OSA group showed a statistical difference when compared to the others $(\mathrm{P}<0.0001)$. There was a significant reduction in the predictive percentage of all pulmonary function variables (CV, FEV1 and FVC) in the severe OSA group, as demonstrated by ANOVA, which found statistical differences when the mean of this group was compared to the others.

Table 3 - Comparative assessment of respiratory and anthropometric parameters according to the severity of obstructive sleep apnea.

\begin{tabular}{|c|c|c|c|c|c|}
\hline \multirow[b]{2}{*}{ VARIABLES } & \multicolumn{4}{|c|}{ GROUPS } & \multirow[b]{2}{*}{$\mathbf{P}^{\mathbf{a}}$} \\
\hline & $\begin{array}{c}\text { Without } \\
\text { OSA } \\
(n=33)\end{array}$ & $\begin{array}{c}\text { Mild } \\
\text { OSA } \\
(n=46)\end{array}$ & $\begin{array}{c}\text { Moderate } \\
\text { OSA } \\
(n=40)\end{array}$ & $\begin{array}{c}\text { Severe } \\
\text { OSA } \\
(n=40)\end{array}$ & \\
\hline Age, years & $38.0 \pm 14.5^{\mathrm{a}}$ & $47.5 \pm 14.2^{b}$ & $51.5 \pm 14.2^{\mathrm{c}}$ & $53.9 \pm 15.4^{\mathrm{d}}$ & 0.0006 \\
\hline BMI, kg/m² & $30.1 \pm 6.8^{a}$ & $32.5 \pm 6.5^{\mathrm{a}}$ & $33.8 \pm 7.6^{\mathrm{a}}$ & $38.0 \pm 9.4^{\mathrm{b}}$ & $<0.0001$ \\
\hline $\mathrm{SpO}_{2} \min (\%)$ & $87.1 \pm 3.9^{\mathrm{a}}$ & $83.0 \pm 5.9^{\mathrm{a}, \mathrm{b}}$ & $78.8 \pm 7.1^{\mathrm{b}}$ & $70.1 \pm 11.7^{\mathrm{c}}$ & $<0.0001$ \\
\hline TV (\%pred) & $99.5 \pm 17.8^{\mathrm{a}}$ & $102.4 \pm 14.5^{\mathrm{a}}$ & $100.5 \pm 19.9^{a}$ & $88.6 \pm 18.8^{b}$ & 0.0011 \\
\hline FEV1 (\%pred) & $89.7 \pm 20.1^{\mathrm{a}}$ & $90.4 \pm 17.4^{\mathrm{a}}$ & $88.3 \pm 18.0^{\mathrm{a}}$ & $75.8 \pm 16.5^{b}$ & 0.0062 \\
\hline FVC (\%pred) & $92.6 \pm 19.1^{\mathrm{a}}$ & $90.8 \pm 15.7^{\mathrm{a}}$ & $89.2 \pm 16.5^{\mathrm{a}}$ & $78.7 \pm 15.4^{\mathrm{b}}$ & 0.0011 \\
\hline
\end{tabular}

Notes: ${ }^{a}$ Anova test for independent samples. Different letters indicate statistically different means obtained by the Tukey test at $5 \%$ significance. BMI: body mass index. $\mathrm{SpO}_{2}$ min: minimum oxygen saturation. $\mathrm{FEV}_{1}$ : forced expiratory volume in 1 second. FVC: forced vital capacity.TV: tidal volume. Pred\%: Predicted percentage. Source: Authors.

Correlations between the severity of the disease and the variables assessed in the study (age, BMI, SpO2min, VC, FEV1 and FVC) were also evaluated. Age and BMI showed positive and weak statistical correlations. In the sample, the older the age, the higher the AHI values (Figure 2) and, therefore, the greater the severity of the disease $\left(r=0.3 ; r^{2}=0.09 ; \mathrm{P}<\right.$ 
0.001). Likewise, the higher the individual's BMI, the greater the severity of OSA $\left(r=0.3 ; r^{2}=0.09 ; \mathrm{P}<0.0001\right)$. In contrast, SpO2min during sleep showed a strong negative correlation with AHI, showing an inverse correlation with the severity of the disease $\left(r=-0.7 ; r^{2}=0.5 ; \mathrm{P}<0.0001\right)$. The pulmonary function variables showed a low negative correlation with severity, the VC correlation value was -0.25 with a coefficient of determination $\left(r^{2}\right)$ calculated at $0.07(\mathrm{P}=0.02)$, FEV1 had a coefficient correlation of -0.32 with $r^{2}=0.10(\mathrm{P}<0.0001)$, while the FVC showed a correlation of -0.35 and $r^{2}=0.12(\mathrm{P}<0.0001)$.

Figure 2 - The apnea-hypopnea index by age, minimum oxygen saturation and forced vital capacity.
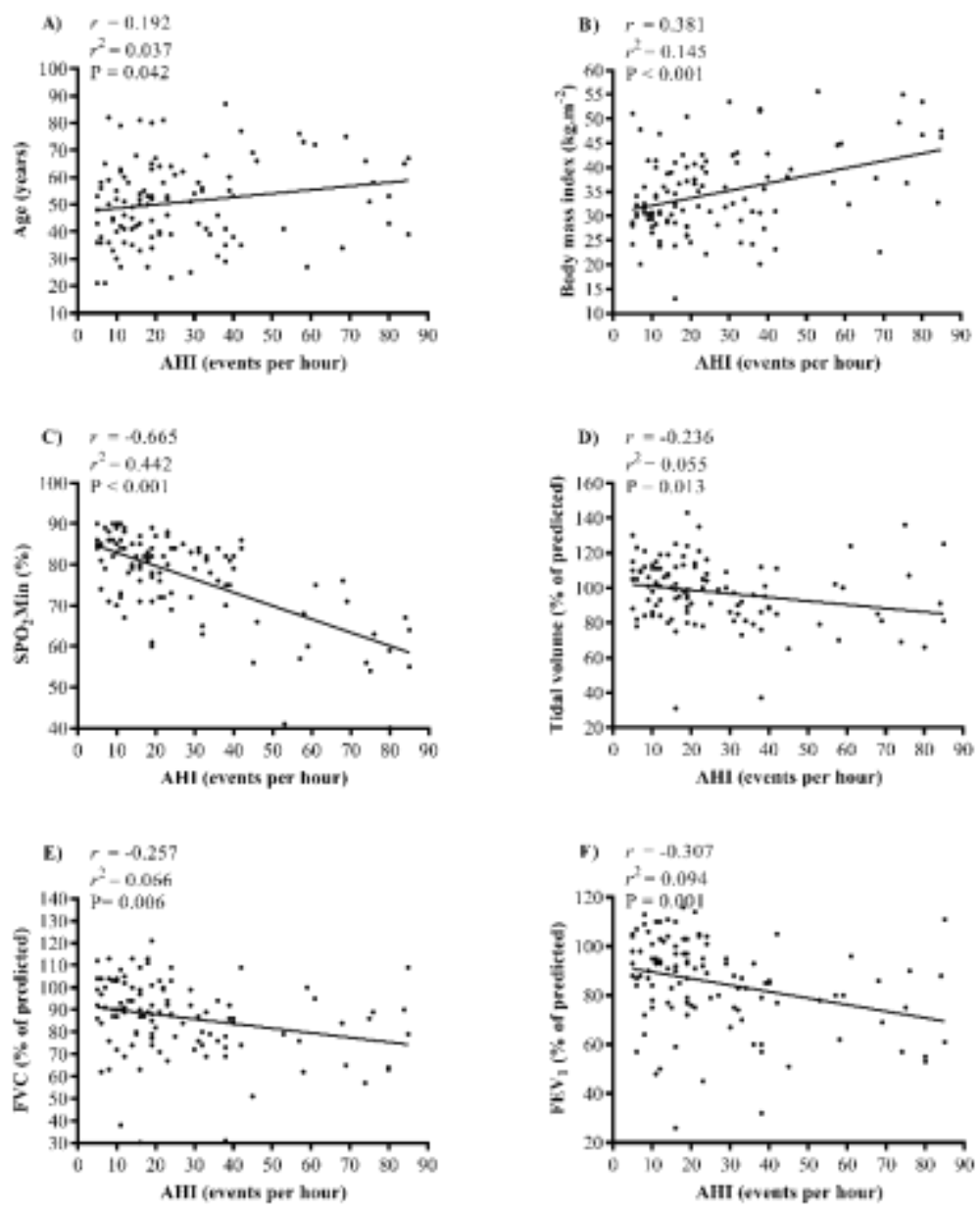

Legend: AHI: Apnea-hypopnea index; SpO2min: minimum oxygen saturation; FVC: forced vital capacity.

Source: Authors.

\section{Discussion}

This study found that half of the patients who underwent PSG had a diagnosis of moderate to severe OSA. These two groups were composed mainly of patients over 60 years of age, with a predominance of males. Heinzer et al. (Heinzer et al., 2015) have reported similar results, thus corroborating the findings of our study. The authors conducted a study in Switzerland with 2,168 patients and observed a higher frequency of cases of moderate and severe OSA in men, while in women mild OSA was more frequent. Furthermore, men aged 60 years or above have twice as much moderate to severe OSA when compared to women. The present study also observed similar results in this age group. This is an important finding, given that cardiovascular events are more prevalent in groups with moderate to severe OSA than patients with mild OSA, or who do not have the condition (Jean-Louis et al., 2009). 
In line with other research (Wali et al., 2017), this study found that men were more affected by severe OSA when compared to women. This may be due to the greater central adiposity of males when compared to females (Degache et al., 2013). As one ages, this pattern tends to increase in both sexes, probably due to the higher incidence of obesity in older individuals (Barbosa et al., 2021; Franklin \& Lindberg, 2015). In this study, in general, the prevalence of OSA increased with age, the same epidemiological behavior observed by Edwards et al. (Edwards et al., 2014). This may be explained by the fact that the ability to maintain tonus in the pharyngeal region changes is affected by aging. Another important finding in the present study is the increase in the mean age, reflected in the heightened severity of the disease, ranging from 38 ( \pm 15 ) years in the group without OSA to $54( \pm 15)$ years in the group with severe OSA. This association was also demonstrated by a positive correlation between AHI and age. The association between increased AHI and aging was also observed in a retrospective study with a larger sample size $(n=23,806)$ (Gabbay \& Lavie, 2012).

In this study, a statistically significant reduction was observed in both FEV1 and FVC, along with an increase in the severity of OSA. These findings corroborate the study carried out by Carvalho et al. (Carvalho et al., 2018). The limitation of respiratory function in these patients seems to be related to the dysfunction of the muscles involved in ventilatory mechanics and to arterial hypoxemia, and to a more pronounced component in individuals with OSA when compared to those who did not have the condition. However, despite the reduction in FEV1 and FVC, no association was found between OSA and chronic obstructive pulmonary disease (COPD) (Vukoja et al., 2017).

Obesity seems to play an important role in the pathogenesis of altered lung function in patients with OSA. A randomized clinical trial undertaken in Brazil has demonstrated a significant improvement in FEV1 and FVC after bariatric surgery when compared to the values of these variables in the preoperative period (Aguiar et al., 2014). Another pathophysiological mechanism underlying pulmonary changes triggered by OSA may be the decreased amount of adiponectin in obese individuals when compared to eutrophic individuals (Masserini et al., 2006). This adipokine exerts anti-inflammatory activity and, in theory, it may reduce the pulmonary effects of the systemic inflammatory reaction and oxidative stress resulting from OSA. However, this hypothesis remains controversial. While one study $(\mathrm{n}=486)$ showed an association with statistical significance between serum adiponectin and OSA, another ( $\mathrm{n}=529)$ did not find any association between adiponectin and lung function (Caspersen et al., 2018; Zeng et al., 2017).

In this study, we observed an association observed between OSA severity and SpO2min during PSG and found that the greater the severity of the disease, the lower the percentage of oxygen saturation. This association may be closely linked to the increase in the formation of reactive oxygen species, triggering oxidative stress and increasing the risk of cardiovascular diseases (Asker et al., 2015; Tichanon et al., 2016). A prospective Japanese study found that urinary excretion of deoxyguanosine (a critical biomarker of oxidative stress in DNA) and the oxygen desaturation index were significantly higher in patients with severe OSA. This seems to show a direct association between oxidative stress and the severity of this disease (Yamauchi et al., 2005), which would contribute to the increase in cardiovascular morbidity and mortality of patients with OSA (Drager et al., 2013).

This study has limitations, such as the lack of analysis of other factors which can alter the value of AHI, for example exercise level. Dietary composition and exercise habits were also not stratified, same for anatomical variations which can affect the diagnosis of OSA. This was also a study restricted for a small group of patients in Vale do São Francisco region, which can limit results generalization for other groups in other areas. A cross-sectional study is also limited in the evaluation of prognosis. Future studies are required for a better understanding of OSA risk factors and severity, leading to the creation of medical protocols for these patients. 


\section{Conclusion}

A greater severity of obstructive sleep apnea was more prevalent in men while impairment of lung function was more pronounced in groups with severe obstructive sleep apnea. Reductions in lung function were also found in this population, with negative linear correlations between ventilatory parameters and severity of obstructive sleep apnea. These findings may contribute to identify groups at risk for obstructive sleep apnea and to design strategies to prevent this condition.

\section{Conflict of interest}

No conflicts of interest have been reported for this article.

\section{Financing source}

No funding.

\section{Acknowledgments}

We thank Clínica Todo Ser, Dr. André Luis de Sousa Bezerra Brandão and Dr. Samira Mariella Gonçalves Pereira Aires Ramos Rocha for logistical support during the research.

\section{Conflict of interest}

No conflicts of interest have been reported for this article.

\section{Financing source}

No funding.

\section{References}

Aguiar, I. C., Freitas, W. R. J., Santos, I. R., Apostolico, N., Nacif, S. R., Urbano, J. J., Fonsêca, N. T., Thuler, F. R., Ilias, E. J., Kassab, P., LeitãoFilho, F. S., Laurino Neto, R. M., Malheiros, C. A., Insalaco, G., Donner, C. F., \& Oliveira, L. V. (2014). Obstructive sleep apnea and pulmonary function in patients with severe obesity before and after bariatric surgery: a randomized clinical trial. Multidisciplinary Respiratory Medicine, 9(1), 43. https://doi.org/10.1186/20496958-9-43

Asker, S., Asker, M., Sarikaya, E., Sunnetcioglu, A., Aslan, M., \& Demir, H. (2015). Oxidative stress parameters and their correlation with clinical, metabolic and polysomnographic parameters in severe obstructive sleep apnea syndrome. International Journal of Clinical and Experimental Medicine, 8(7), 1144911455 .

Barbosa, I. dos S., Souza, J. C., Muller, P. de T. G., Brito, P. O. C., Augusto, C. T., \& Cantarelli, I. de A. C. (2021). Avaliação dos distúrbios do sono de pacientes submetidos à polissonografia. Research, Society and Development, 10(1), e40110111738. https://doi.org/10.33448/rsd-v10i1.11738

Canales, M. T., Hagen, E. W., Barnet, J. H., Peppard, P. E., \& Derose, S. F. (2018). Sleep Apnea and kidney function trajectory: results from a 20-year longitudinal study of healthy middle-aged adults. Sleep, 41(1). https://doi.org/10.1093/sleep/zsx181

Capalbo, L. C., Dal-Fabbro, R., Donine, A. L. M. de A., Saraiva, J. S., Bigliazzi, R., Weber, S. A. T., \& Bertoz, A. P. M. (2021). Rapid maxillary expansion as a treatment for obstructive sleep apnea syndrome in children and adolescents: an evaluation by polysomnography and quality of life. Research, Society and Development, $10(2)$, e52710212825. https://doi.org/10.33448/rsd-v10i2.12825

Carvalho, L. P. da C., Gomes, M. B. da C., Oliveira, Í. C. da S., Santos, P. H. S., De Oliveira II, A. C., Vitavar, L. M. G., \& Alves, H. B. (2020). Responses of myokines concentrations from exercise stimulus: a systematic review. Revista Brasileira de Fisiologia Do Exercício, $19(5), 421$. https://doi.org/10.33233/rbfex.v19i5.4393

Carvalho, T. M. da C. S., Soares, A. F., Climaco, D. C. S., Secundo, I. V., \& Lima, A. M. J. de. (2018). Correlation of lung function and respiratory muscle strength with functional exercise capacity in obese individuals with obstructive sleep apnea syndrome. Jornal Brasileiro de Pneumologia, 44(4), 279-284. https://doi.org/10.1590/s1806-37562017000000031

Caspersen, N. F., Røsjø, H., Flyvbjerg, A., Bjerre, M., Randby, A., Hrubos-strøm, H., Omland, T., \& Einvik, G. (2018). The association between circulating adiponectin levels, lung function and adiposity in subjects from the general population; data from the Akershus Sleep Apnea Project. BMC Pulmonary Medicine; 18, 54. https://doi.org/10.1186/s12890-018-0618-4 
Chen, V. G., Fonseca, V. M. G. da, Amaral, J. B., Camargo-Kosugi, C. M., Moreira, G., Kosugi, E. M., \& Fujita, R. R. (2020). Inflammatory markers in palatine tonsils of children with obstructive sleep apnea syndrome. Brazilian Journal of Otorhinolaryngology, 86(1), 23-29. https://doi.org/10.1016/j.bjorl.2018.08.001

Cunha, T. C. A., Guimarães, T. M., Almeida, F. R., Haddad, F. L. M., Godoy, L. B. M., Cunha, T. M., Silva, L. O., Tufik, S., \& Bittencourt, L. (2020). Using craniofacial characteristics to predict optimum airway pressure in obstructive sleep apnea treatment. Brazilian Journal of Otorhinolaryngology, 86(2), 174179. https://doi.org/10.1016/j.bjorl.2018.10.012

Da Cruz Carvalho, L. P., De Souza, S. S. N., Souza, D. C., Araujo, F. D. S., Carvalho, F. O., De Moraes, J. F. V. N., \& Gomes, J. L. D. B. (2020). Analysis of glycemic safety of a moderate-intensity resistance exercise session in patients with diabetes type 1. Revista Brasileira de Fisiologia do Exercício, 19(1), 16. https://doi.org/10.33233/rbfe.v19i1.3905

Degache, F., Sforza, E., Dauphinot, V., Celle, S., Garcin, A., Collet, P., Pichot, V., Barthélémy, J.-C., \& Roche, F. (2013). Relation of central fat mass to obstructive sleep apnea in the elderly. Sleep, 36(4), 501-507. https://doi.org/10.5665/sleep.2532

Drager, L. F., Togeiro, S. M., Polotsky, V. Y., \& Lorenzi-Filho, G. (2013). Obstructive sleep apnea: a cardiometabolic risk in obesity and the metabolic syndrome. Journal of the American College of Cardiology, 62(7), 569-576. https://doi.org/10.1016/j.jacc.2013.05.045

Edwards, B. A., Wellman, A., Sands, S. A., Owens, R. L., Eckert, D. J., White, D. P., \& Malhotra, A. (2014). Obstructive sleep apnea in older adults is a distinctly different physiological phenotype. Sleep, 37(7), 1227-1236. https://doi.org/10.5665/sleep.3844

Franklin, K. A., \& Lindberg, E. (2015). Obstructive sleep apnea is a common disorder in the population-a review on the epidemiology of sleep apnea. Journal of Thoracic Disease, 7(8), 1311-1322. https://doi.org/10.3978/j.issn.2072-1439.2015.06.11

Gabbay, I. E., \& Lavie, P. (2012). Age- and gender-related characteristics of obstructive sleep apnea. Sleep \& Breathing, 16(2), 453-460. https://doi.org/10.1007/s11325-011-0523-z

Gautier-Veyret, E., Bäck, M., Arnaud, C., Belaïdi, E., Tamisier, R., Lévy, P., Arnol, N., Perrin, M., Pépin, J. L., \& Stanke-Labesque, F. (2018). Cysteinylleukotriene pathway as a new therapeutic target for the treatment of atherosclerosis related to obstructive sleep apnea syndrome. Pharmacological Research, 134, 311-319. https://doi.org/10.1016/j.phrs.2018.06.014

Genta, P. R., Schorr, F., Edwards, B. A., Wellman, A., \& Lorenzi-Filho, G. (2020). Discriminating the severity of pharyngeal collapsibility in men using anthropometric and polysomnographic indices. Journal of Clinical Sleep Medicine, 16(9), 1531-1537. https://doi.org/10.5664/jcsm.8600

Gottlieb, D. J., \& Punjabi, N. M. (2020). Diagnosis and Management of obstructive sleep apnea. JAMA, 323(14), 1389. https://doi.org/10.1001/jama.2020.3514

Heinzer, R., Vat, S., Marques-Vidal, P., Marti-Soler, H., Andries, D., Tobback, N., Mooser, V., Preisig, M., Malhotra, A., Waeber, G., Vollenweider, P., Tafti, M., \& Haba-Rubio, J. (2015). Prevalence of sleep-disordered breathing in the general population: the HypnoLaus study. The Lancet Respiratory Medicine, 3(4), 310-318. https://doi.org/10.1016/S2213-2600(15)00043-0

Jean-Louis, G., Zizi, F., Brown, D., Ogedegbe, G., Borer, J., \& McFarlane, S. (2009). Obstructive sleep apnea and cardiovascular disease: evidence and underlying mechanisms. Minerva Pneumologica, 48(4), 277-293.

Jehan, S., Myers, A. K., Zizi, F., Pandi-Perumal, S. R., Jean-Louis, G., \& McFarlane, S. I. (2018). Obesity, obstructive sleep apnea and type 2 diabetes mellitus: Epidemiology and pathophysiologic insights. Sleep Medicine and Disorders, 2(3), 52-58.

Liu, W.-T., Wu, H., Juang, J.-N., Wisniewski, A., Lee, H.-C., Wu, D., \& Lo, Y.-L. (2017). Prediction of the severity of obstructive sleep apnea by anthropometric features via support vector machine. PLOS ONE, 12(5), e0176991. https://doi.org/10.1371/journal.pone.0176991

Maresky, H. S., Klar, M. M., Tepper, J., Gavriel, H., Ziv Baran, T., Shapiro, C. M., \& Tal, S. (2019). Mandibular width as a novel anthropometric measure for assessing obstructive sleep apnea risk. Medicine, 98(4), e14040. https://doi.org/10.1097/MD.0000000000014040

Masserini, B., Morpurgo, P. S., Donadio, F., Baldessari, C., Bossi, R., Beck-Peccoz, P., \& Orsi, E. (2006). Reduced levels of adiponectin in sleep apnea syndrome. Journal of Endocrinological Investigation, 29(8), 700-705. https://doi.org/10.1007/BF03344179

Mazzotti, D. R., Keenan, B. T., Lim, D. C., Gottlieb, D. J., Kim, J., \& Pack, A. I. (2019). Symptom Subtypes of obstructive sleep apnea predict incidence of cardiovascular outcomes. American Journal of Respiratory and Critical Care Medicine, 200(4), 493-506. https://doi.org/10.1164/rccm.201808-1509OC

Modena, D. A. O., Cazzo, E., Cândido, E. C., Baltieri, L., Silveira, L. J. B. da, Almeida, A. M. N. de, Gobato, R. C., \& Chaim, E. A. (2017). Obstructive sleep apnea syndrome among obese individuals: A cross-sectional study. Revista da Associação Médica Brasileira, 63(10), 862-868. https://doi.org/10.1590/18069282.63 .10 .862

Osman, A. M., Carter, S. G., Carberry, J. C., \& Eckert, D. J. (2018). Obstructive sleep apnea: current perspectives. Nature and Science of Sleep, 10, $21-34$. https://doi.org/10.2147/NSS.S124657

Patil, S. P., Ayappa, I. A., Caples, S. M., Kimoff, R. J., Patel, S. R., \& Harrod, C. G. (2019). Treatment of adult obstructive sleep apnea with positive airway pressure: an american academy of sleep medicine clinical practice guideline. Journal of Clinical Sleep Medicine, 15(02), 335-343. https://doi.org/10.5664/jcsm.7640

Peppard, P. E., Young, T., Barnet, J. H., Palta, M., Hagen, E. W., \& Hla, K. M. (2013). Increased prevalence of sleep-disordered breathing in adults. American Journal of Epidemiology, 177(9), 1006-1014. https://doi.org/10.1093/aje/kws342

Qian, Y., Xu, H., Wang, Y., Yi, H., Guan, J., \& Yin, S. (2016). Obstructive sleep apnea predicts risk of metabolic syndrome independently of obesity: a metaanalysis. Archives of Medical Science, 12(5), 1077-1087. https://doi.org/10.5114/aoms.2016.61914

Reutrakul, S., \& Mokhlesi, B. (2017). Obstructive sleep apnea and diabetes. Chest, 152(5), 1070-1086. https://doi.org/10.1016/j.chest.2017.05.009 
Souto, V. F., Da Silva, C. A., Lins, N. C. de M., Araújo, M. L. D., \& Costa, A. D. S. (2020). Impact of dietary composition and resistance training on cardiovascular risk indicators and abdominal fat in older adult women. Revista Brasileira de Fisiologia do Exercício, 19(6), 489. https://doi.org/10.33233/rbfex.v19i6.4280

Sreedharan, S., Agrawal, P., Rajith, R., Nair, S., Sarma, S., \& Radhakrishnan, A. (2016). Clinical and polysomnographic predictors of severe obstructive sleep apnea in the South Indian population. Annals of Indian Academy of Neurology, 19(2), 216-220. https://doi.org/10.4103/0972-2327.173315

Sun, S., Zhai, H., Zhu, M., Wen, P., He, X., \& Wang, H. (2019). Insulin resistance is associated with Sfrp5 in obstructive sleep apnea. Brazilian Journal of Otorhinolaryngology, 85(6), 739-745. https://doi.org/10.1016/j.bjorl.2018.07.002

Sweed, R. A., Hassan, S., ElWahab, N. H. A., Aref, S. R., \& Mahmoud, M. I. (2019). Comorbidities associated with obstructive sleep apnea: a retrospective Egyptian study on 244 patients. Sleep and Breathing, 23(4), 1079-1085. https://doi.org/10.1007/s11325-019-01783-w

Tichanon, P., Wilaiwan, K., Sopida, S., Orapin, P., Watchara, B., \& Banjamas, I. (2016). Effect of Continuous positive airway pressure on airway inflammation and oxidative stress in patients with obstructive sleep apnea. Canadian Respiratory Journal, 2016 , 3107324. https://doi.org/10.1155/2016/3107324

Veasey, S. C., \& Rosen, I. M. (2019). Obstructive sleep apnea in adults. New England Journal of Medicine, 380(15), 1442-1449. https://doi.org/10.1056/NEJMcp1816152

Vukoja, M., Milicic, D., Bokan, A., Andrijevic, I., \& Kopitovic, I. (2017). Lung function in patients with obstructive sleep apnoea. ERJ Open Research, 3(Suppl 1), P14. https://doi.org/10.1183/23120541.sleepandbreathing-2017.P14

Wali, S. O., Abalkhail, B., \& Krayem, A. (2017). Prevalence and risk factors of obstructive sleep apnea syndrome in a Saudi Arabian population. Annals of Thoracic Medicine, 12(2), 88-94. https://doi.org/10.4103/1817-1737.203746

Yamauchi, M., Nakano, H., Maekawa, J., Okamoto, Y., Ohnishi, Y., Suzuki, T., \& Kimura, H. (2005). Oxidative stress in obstructive sleep apnea. Chest, 127(5), 1674-1679. https://doi.org/10.1378/chest.127.5.1674

Zeng, F., Wang, X., Hu, W., \& Wang, L. (2017). Association of adiponectin level and obstructive sleep apnea prevalence in obese subjects. Medicine, 96(32), e7784. https://doi.org/10.1097/MD.0000000000007784 